\title{
Social Influences on Flood Preparedness and Mitigation Measures Adopted by People Living with Flood Risk
}

\author{
Donald Houston ${ }^{1, *(D)}$, Tom Ball ${ }^{2}$, Alan Werritty ${ }^{3}$ and Andrew R. Black $^{3} \mathbb{D}$ \\ 1 School of the Environment, Geography \& Geoscience, University of Portsmouth, Portsmouth PO1 3HE, UK \\ 2 Department of Archaeology, Anthropology and Geography, University of Winchester, \\ Winchester SO22 4NR, UK; tom.ball@winchester.ac.uk \\ 3 Geography \& Environmental Science, University of Dundee, Dundee DD1 4HN, UK; \\ a.werritty@dundee.ac.uk (A.W.); a.z.black@dundee.ac.uk (A.R.B.) \\ * Correspondence: donald.houston@port.ac.uk
}

Citation: Houston, D.; Ball, T.; Werritty, A.; Black, A.R. Social Influences on Flood Preparedness and Mitigation Measures Adopted by People Living with Flood Risk. Water 2021, 13, 2972. https://doi.org/ $10.3390 / w 13212972$

Academic Editors: David Proverbs and Bingunath Ingirige

Received: 3 September 2021

Accepted: 15 October 2021

Published: 21 October 2021

Publisher's Note: MDPI stays neutral with regard to jurisdictional claims in published maps and institutional affiliations.

Copyright: (c) 2021 by the authors. Licensee MDPI, Basel, Switzerland. This article is an open access article distributed under the terms and conditions of the Creative Commons Attribution (CC BY) license (https:/ / creativecommons.org/licenses/by/ $4.0 /)$.
Abstract: This paper aims to analyse evidence, based on one of the largest and most representative samples of households previously flooded or living with flood risk to date, of social patterns in a range of flood resilience traits relating to preparedness prior to a flood (e.g., property adaptations, contents insurance, etc.) and mitigations enacted during and immediately following a flood (e.g., receiving a warning, evacuation into temporary accommodation, etc.). The data were collected from a 2006 survey of 1223 households from a variety of locations across Scotland between one and twelve years after major local floods. Our analysis identifies remarkably few social differences in flood preparedness and mitigation measures, although some aspects of demography, housing and length of residence in an area, as well as personal flood history, are important. In light of this finding, we argue that social differences in vulnerability and resilience to flooding arise from deep-seated socio-economic and socio-spatial inequalities that affect exposure to flood risk and ability to recover from flood impacts. The engrained, but well-meaning, assumption in flood risk management that impoverished households and communities are lacking or deficient in flood preparedness or mitigation knowledge and capabilities is somewhat pejorative and misses fundamental, yet sometimes invisible, social stratifications play out in subtle but powerful ways to affect households' and communities' ability to avoid and recover from floods. We argue that general poverty and inequality alleviation measures, such as tax and welfare policy and urban and community regeneration schemes, are likely to be as, if not more, important in alleviating social inequalities in the long-term impacts of floods than social targeting of flood risk management policy.

Keywords: flood vulnerability; flood resilience; social inequality

\section{Introduction}

Much progress has been made in the flooding vulnerability and resilience literature of the importance of social disadvantage in shaping flood vulnerability and resilience. The interest reflects strong policy drivers, with an active academic-policy interface on environmental social justice and 'fair' management approaches [1-4]. There is also the backdrop of increasing risk due to climate change, with an awareness that personal and environmental factors should be set alongside social factors in setting policy [5,6]. Previous research has clearly established that household resources and community assets are consistently linked to ability to recover from flood events, particularly in the long-term [7]. However, the precise mechanisms behind this relationship remain unclear, with policy interventions often assuming an information-deficit (lack of knowledge and understanding) model to explain lower levels of uptake of flood preparedness measures and lower uptake of assistance available during and after a flood observed among socially-disadvantaged groups. This paper aims to provide evidence, based on one of the largest and most representative samples of households previously flooded or living with flood risk to date, of social patterns 
in a range of flood preparedness and mitigations. The original survey was conducted in 2006 in a range of recently flooded locations across Scotland, spanning fluvial, coastal and urban surface pluvial floods [8] and has been further analysed by Houston et al. [7].

The initial publication [8] took the form of a report published by the Scottish Government who had funded the project. In that report, no attempt was made to explore in-depth issues around flood preparedness and mitigation measures that might be undertaken by households at risk of being flooded. This report was the first in the UK to analyse the social impacts of flooding, was broad brush and inevitably individual issues (such as flood preparedness and the uptake of mitigation measures) were afforded limited treatment; indeed, the only analytical treatment of flood preparedness and mitigation was disaggregation by whether a household had been flooded or not, with no analysis whatever of social patterns, which this paper now undertakes. The more recent article [7] explored the resilience of vulnerable social groups to flooding as reflected in the impacts of floods reported by households, explicitly taking into account contrasting patterns of response during post flood recovery, which, for some sites, extended over many years. The analysis reported in the current paper is focused on flood preparedness (prior to the flood) and flood mitigation (during and immediately after the flood), which were only used as explanatory factors alongside a large number of others in Houston et al. [7]. In the current paper, flood preparedness and mitigation take centre stage as the focus of analysis according to a wide range of social factors and as dependent variables in models. Taken together, Werritty et al. [8], Houston et al. [7] and the current paper provide one of the best, and arguably the most detailed, accounts of the social vulnerability and resilience to flooding yet undertaken from a single data set. The current paper is the first detailed statistical analysis of social patterns in flood preparedness and mitigations, with most of the previous quantitative studies focusing on impacts on health and wellbeing.

Assumptions are often made that lower-income households and socially-deprived communities lack knowledge and organisational capacity to put in place effective flood preparedness (e.g., property-level flood alleviation) and adequate uptake of or receptiveness to emergency responses (e.g., receiving and acting on flood warnings, deployment and uptake of assistance from a range of sources). In turn, extra investment is justified in these warning and preparedness initiatives on the basis of improving capacity, in the interests of fairness (termed the 'Rawlsian' approach by Sayers et al. [4]). Our analysis, however, identifies remarkably few, and mostly modest in scale, social differences in flood preparedness and mitigations. In light of this finding, we argue that social differences in vulnerability and resilience to flooding arise from deep-seated socio-economic and socio-spatial inequalities that affect exposure to flood risk and ability to recover from flood impacts. The engrained assumption in flood risk management that impoverished households and communities are lacking or deficient in flood preparedness or mitigation capabilities is somewhat pejorative and misses fundamental, yet sometimes invisible, social stratifications that play out in subtle but powerful ways to affect households' and communities' ability to avoid and recover from floods. Many of these social disadvantages have their roots far from flood preparedness and mitigation: although they may affect the capacity to cope and recover effectively, sometimes in subtle ways, for example the pressures and limitations arising from poverty, family breakdown, drug and alcohol misuse, poor mental health and strong ontological connections to, and dependencies on, local places, communities and home that can be fundamentally damaged by a flood $[9,10]$.

\section{Flooding Resilience}

The concept of environmental vulnerability frames why certain locations and population sub-groups are more exposed to, and less able to withstand or recover from, natural hazards [11,12]. Vulnerability to natural hazards has been linked to underlying socio-economic inequalities, social relations, political priorities and values, and systems of governance and representation [13,14], and environmental issues more generally seen as an arena of inequality and injustice [15] and political power and exploitation [16]. Na- 
tional level spatial vulnerability quantification remains an important plank of flood risk management policy. The wider concept of flood vulnerability was incorporated into the Neighbourhood Flood Vulnerability Index (NFVI), by Sayers et al. [4], building on Lindley et al. [5] and Kazmierczak et al. [17]. The NFVI develops and refines previous national geographical indices, such as those of Tapsell et al. [11]. Such indices, seeking comprehensive coverage, rely on national metric-based indicators such as Census and deprivation data, whose links to preparedness and mitigation action are not well established. Indeed, the NFVI, while an important tool in the holistic national assessment of flood risk, has been based on indicators over which a flood risk management policy has limited or no control [4].

The influential and widely-used definition of vulnerability proposed by Cutter [18] differentiates between three components: exposure; resistance; and resilience. Exposure relates to level risk of floods of a given frequency and magnitude. Resistance relates to the ability to withstand a flood, while resilience is the set of processes facilitating or hindering recovery and adaptation. The term 'resilience' has been defined in a manner that overlaps 'resistance' in some previous studies, with further subdivision, into 'engineered' resilience and 'community/societal' resilience. Although an argument has been made for a consistent typology for resilience encompassing this subdivision [19], the separation of resistance activity as the ability to withstand (e.g., actions to prevent dangers from flood water and/or the ingress of water) from resilience as the ability to recover following a flood event, is a longstanding terminological distinction in UK flood risk management, having been adopted by the principal authorities [20,21]. Our analysis therefore also adopts this, focusing on two social elements of resilience (although to a lesser extent they may also enhance short-term resistance): flood preparedness and flood mitigation. In the analysis reported in this paper, we define flood preparedness as features in place prior to a flood event (specifically: property-level flood alleviation measures; awareness of flood risk; knowledge of what to do in a flood; and the uptake of insurance). We define flood mitigation as a range of actions taken or assistances/services accessed during and immediately after a flood in order to lessen its impact (specifically: receiving a warning; taking actions, such as removing valuable items; and receiving assistance, such as being allocated temporary accommodation).

\subsection{Flood Preparedness}

Preparedness for flooding involves a complex set of drivers of which a key element is whether or not a property has been protected by property flood resilience measures (PFR) (previously more widely referred to as property-level protection), which seek to impede the ingress of flood water (e.g., door guards and airbrick covers) and lower the impact (e.g., elevating kitchen appliances, re-locating electrical sockets and replacing carpets with hard floor surfaces). Property flood resilience measures had not been widely promoted by the time of the 2006 survey, although they are now viewed as a key part of the tool kit for managing flooding [21]. Important limits to their uptake in England were noted by Sayers et al. [4], including cost, tenancy type (rented vs. owned), bureaucratic burdens and transience in communities. More recently, Glencross et al. ([22], p. 37) have concluded "there is no single or quick fix to increase PFR uptake" from in-depth interviews with individuals in Scotland whose properties have been flooded within the last three years. Flood preparedness can also involve taking out insurance, the take up of which involves complex issues of availability [23] and affordability [24]. Contents insurance take-up is particularly low among those on low incomes, with Watkiss et al. [25] noting that many in the lowest income decile had no insurance at all. The Flood Re programme in the UK [26], which commenced in April 2016, seeks to address both issues by selective capping of premium levels and promoting greater availability, while maintaining private sector provision.

Alongside and interlinked with these preparedness measures sits the longer-term risk-reducing objectives of planning policy. The National Planning Policy framework in 
England, and its equivalent in the devolved administrations, attempt to guide planning authorities away from non-essential building of all types in high flood risk areas. Surface water and groundwater flooding are included in the planning authorities' flood risk assessments, as mandated by the Pitt Review into the 2007 floods [27]. The policy interlinks with insurability by excluding from the Flood Re scheme residential property built in high flood risk areas after 2009. However, there is evidence that residential building in areas of relatively high flood risk has continued, to a greater extent in areas that may have higher community flood vulnerability in parts of the UK experiencing high demand for housing. In contrast to the situation in Scotland [23], a recent study of England and Wales by Rözer and Surminski [28] found that more homes were built in high flood risk areas ( $1 \%$ or higher annual chance of flooding $(0.5 \%$ for coastal flooding)) in 'struggling or declining' neighbourhoods between 2008 and 2018 compared with other areas, though future increases in areas benefiting from flood defences are excluded. This finding suggests that areas requiring flood preparedness may be growing, rather than shrinking, despite the planning and insurance policies and measures that are in place, with urban development reproducing and compounding existing inequalities through affordability, market power and political voice [29].

\subsection{Flood Mitigation}

A variety of mitigating factors have been linked with lowered flood impacts: receiving a flood warning; taking actions prior to a flood; and receiving assistance [30,31]. The availability and use made of flood warnings were identified as key elements of mitigating the impact of a flood [32].

Important mediators are previous flood experience (a sense that lack of prior experience leads to a perceived lack of need for a warning), personality and risk appetite [32], but linguistic and cultural barriers can also be important [33]. There is evidence that both flood warning uptake and actions based on a flood warning are mediated by community vulnerability, although recent research in this area is sparse.

Income levels also serve to differentiate resilience levels with those on lower incomes less likely to have financial resources (or insurance, as noted by Penning-Rowsell [24]) to replace items, repair properties and pay for re-location [8]. People working in lower-skilled occupations may face less flexibility in taking time off work and thus be able to engage with and adopt assistance on offer to flood victims, and may have less social and cultural capital, including experience or capacity to negotiate bureaucratic processes in the mitigation and recovery phases after a flood event [10]. Renters may have less control over rehousing and repairs than homeowners [30].

Many studies have suggested that geographical context shapes vulnerability and resilience to flooding with areas of social deprivation or 'other' populations (e.g., ethnic minorities) being afforded lower priority in both immediate flood recovery and in subsequent support $[10,34,35]$. By contrast, more cohesive communities can provide greater informal social support via family and friendship networks $[3,36,37]$. Many studies report on the widespread destruction and displacement of households in New Orleans, USA, following Hurricane Katrina in 2005 with lower socio-economic status neighbourhoods recording the most severe impacts $[38,39]$. Looking at longer-term resettlement, middle-income neighbourhoods appear to be recovering the slowest, lacking the private resources to fund recovery and with lower eligibility for publicly-funded programmes [40].

\section{Methods and Data}

This paper draws on systematic quantitative data from a structured questionnaire survey of 1223 households from a variety of locations across Scotland between one and twelve years after major local floods (for further detail on data collection and subsequent analyses, see Werritty et al. [8] and Houston et al. [7]). Scotland was chosen for fieldwork because of a number of significant floods since the early 1990s (see Black and Burns [41]) and increasing concern by the Scottish Government on how to better manage flood risk. 
This concern was subsequently addressed in the Flood Risk Management (Scotland) Act 2009, which, unlike England and Wales, retained local authorities as primarily responsible for delivering flood risk management, but with the Scottish Environment Protection Agency providing national coverage of flood warnings and mapping of flood risk areas. A key element in this legislation was a requirement that the social costs of flooding be taken into account in flood risk management alongside the more readily determined economic costs, a concern that continues to exercise the Scottish Government [3].

\subsection{Sampling and Data Collection}

Areas that had experienced flooding were identified from the Scottish Environment Protection Agency's 2006 Indicative River and Coastal Flood Map, information in local authority reports, and from telephone contact with staff from local authorities and the Scottish Environment Protection Agency. Residential addresses in these areas were randomly sampled (or fully sampled in areas with smaller flood envelopes).

A household was considered to have been flooded if flood water entered the home (or garage or outhouse in the pilot in Brechin-see Table 1). Areas were selected in order to give a mix of types of flood-fluvial/river, pluvial/surface and coastal—as well as a range of types of areas-remote/rural (Culloden, Corpach, Eyemouth, Dunoon, Menstrie, Newcastleton, Orkney and Shetland), towns (Elgin, Forres and Hawick) and cities (Edinburgh, Glasgow and Perth).

Table 1. Response rates by survey location.

\begin{tabular}{cccc}
\hline Survey Location & Properties Contacted & Returned Questionnaires & Response Rate (\%) \\
\hline Brechin & 67 & 46 & 68.7 \\
Edinburgh (Braid Burn and & 539 & 316 & 58.6 \\
Water of Leith) & 412 & 237 & 57.5 \\
Elgin & 444 & 261 & 58.8 \\
Forres & 262 & 113 & 43.1 \\
Glasgow (Shettleston) & 115 & 55 & 47.8 \\
Hawick & 246 & 126 & 51.2 \\
Perth & 236 & 69 & 29.2 \\
Scattered rural and coastal & 2321 & 1223 & 52.7 \\
(by post) & & \\
TOTAL & & & \\
\hline
\end{tabular}

The survey was undertaken via a questionnaire designed to be completed by respondents. In cities and larger towns, the questionnaire was delivered by hand to each household and usually collected the next day, with a researcher assisting in its completion when necessary. Collection was focused on evenings and weekends to maximise the response rate, with up to two return visits being made. Freepost envelopes were provided when follow up visits still failed to make contact with an adult member of the household.

Address lists of properties in areas that had been flooded were generated from lists of postal addresses. In areas with smaller flood envelopes (Elgin, Forres and Hawick), questionnaires were delivered to all households within the historic flood envelope. In Edinburgh and Perth where large numbers of properties were flooded, samples were drawn of properties closest to the river with an upper limit in any one survey site of 500 properties. The water, sewerage and drainage provider-Scottish Water-provided addresses of properties in Shettleston in the east end of Glasgow that experienced pluvial flooding in 2002 from which a geographically clustered random sample of 262 properties was drawn. For scattered rural inland and coastal locations, the questionnaire was delivered by post, respondents again being provided with a freepost envelope for return.

The number of properties contacted, the number of returned questionnaires and associated response rate in each survey site are listed in Table 1. Overall, 2321 properties were contacted and 1223 completed questionnaires were obtained, representing a response 
rate of $52.7 \%$. Of the 1223 completed questionnaires, 609 were from households that had been flooded. Non-flooded households $(n=614)$ either escaped flooding due to undesigned micro-topographic features (e.g., elevated properties, kerbs, walls and slopes) or designed property-level alleviation measures (e.g., flood guards), or because the occupier had taken up residence after the flood ( $\mathrm{n}=342$ households). The flood preparedness questions were asked of all households, except flood awareness prior to the flood, which could only be asked of those who had been flooded. Flood mitigation questions (e.g., whether they received a warning) were only applicable to those who had been flooded.

While older people (aged $70+)$ are over-represented in our returns $(22.2 \%$ of survey returns versus $11.2 \%$ of the Scottish population recorded in the 2001 Census), lower socioeconomic groups are relatively well represented. For example, $9.9 \%$ of our survey returns fall into the 'elementary' (i.e., unskilled) occupational category versus $12.7 \%$ in Scotland as a whole, a difference of only $2.8 \%$. The under-representation of local authority tenants is slightly greater $(15.8 \%$ versus $21.6 \%$ nationally) (all figures for Scotland for comparison are taken from the 2001 Census of Population). The number of responses in categories used in the analysis is provided later in the sample size columns (labelled ' $n$ ') in tables contained in Section 4. The survey was undertaken during the period Feb-Sept 2006 of households within selected areas that had been flooded during the period 1993-2005. Detailed comparisons of flooded and non-flooded households in the sample according to social traits and flood awareness and behaviours were reported in Werritty et al. [8]. Statistical analysis of social gradients in short- and long-term flood impacts and recovery reported by households in the sample can be found in Houston et al. [7]. This paper reports social patterns in flood preparedness and mitigation. Although the data were collected more than a decade ago, we have come to realise that the sample is one of the largest and most representative of residents in flood-risk areas, and social patterns in flooding vulnerability and resilience are likely to display persistence over time.

\subsection{Measurements}

Four aspects of flood preparedness prior to the flood were measured: (i) whether property-level flood alleviation work had been undertaken prior to the flood; (ii) whether the household was aware of flood risk prior to the flood; (iii) whether the household is confident that they know what to do in the event of a future flood; and (iv) whether contents insurance was in place prior to the flood.

Three aspects of flood impact mitigation at the time of the flood were measured: (a) whether the household took actions during the flood to reduce impact; (b) whether the household received a flood warning (from any source, not just a formal flood warning); and (c) whether the household received any assistance during or after the flood.

\subsection{Analysis}

Initial data description and exploration was undertaken using cross-tabulations of the seven measures of flood preparedness and mitigation outlined above against a range of key demographic, social, housing, residential and personal flood history traits (reported in Section 4). The statistical significance of these cross-tabulations was assessed using Chi-square tests.

In order to control for confounding between the social factors investigated, multivariate logistic regression modelling was undertaken with each of the above seven measures as binary dependent variables (no/yes, coded as 0 or 1, respectively). Co-variates or independent variables in models were: presence of children in the household; presence of elderly (aged 70 years plus) in the household; presence of a disabled person in the household; household income; occupational class of the household's primary earner; highest qualification of the household's primary earner; housing tenure (rent/own, including type of landlord and whether homeowners have a mortgage); housing type (house/flat etc); duration of residence (years); urban/rural location; and type of flood (fluvial/pluvial/coastal). All variables were entered in a backward stepwise procedure. In a small number of cases, 
certain variables were excluded before the stepwise procedure was commenced on the basis that they produced unstable or counter-intuitive coefficients. Only final model specifications are reported. Insignificant variables are retained in the final model after the stepwise procedure in two of the models, but only statistically significant parameters (odds ratios and constants) have been reported. Odds ratios are a way of standardising beta coefficients in order to make them directly comparable between variables that may be in different units or have different variances. An odds ratio takes a value below unity (1.0) if the variable effect is to lower the probability of an occurrence ( 1 rather than 0 ) in the binary dependent variable. Conversely, an odds ratio takes a value above unity (1.0) if the variable effect is to raise the probability of an occurrence in the binary dependent variable. Constants reflect the prevailing level of probability of an occurrence in the binary dependent variable independent of any of the co-variates.

Preparedness measures (i) and (iii) (respectively: whether property-level flood alleviation work had been undertaken prior to the flood, and whether the household is confident that they know what to do in the event of a future flood) were run as separate models for those who had been flooded and those who moved into the area after the flood, because having been flooded or living in the property at the time of the flood have such dominant impacts on these two measures.

\section{Results}

\subsection{Preparedness}

Overall, just over half (52\%) of households in previously flooded areas had undertaken property-level flood alleviation (we use the term 'property-level flood alleviation' to reflect the wording used in our questionnaire; this term can be considered equivalent to the now more widely used terms 'property-level protection' and 'property flood resilience') (Table 2). Note that around half of our sample had previously been flooded (part of our sample design in order to capture information on mitigation measures during and immediately after a flood), therefore flood preparedness is likely to be higher in our sample than in an area at-risk but not having experienced a flood event in recent years (assuming that having been flooded encourages people to adopt property-level flood alleviation). Housing characteristics and length of residence in the property are the factors most strongly associated with uptake of property-level flood alleviation (Table 3), with no consistent statistically significant relationships with any demographic or social traits (only qualifications display a statistically significant relationship with property-level flood alleviation but do not follow a consistent pattern with increasing or decreasing level of qualification) (Table 2).

Table 2. Flood resilience by demographic and social characteristics. (\% of households).

\begin{tabular}{|c|c|c|c|c|c|c|c|c|}
\hline & \multirow[b]{2}{*}{$\begin{array}{c}\text { All } \\
\text { (Flooded) }\end{array}$} & \multicolumn{4}{|c|}{ Flood Preparedness } & \multicolumn{3}{|c|}{ Flood Mitigation } \\
\hline & & $\begin{array}{l}\text { Property- } \\
\text { Level Flood } \\
\text { Alleviation } \\
\text { Undertaken }\end{array}$ & $\begin{array}{c}\text { Was Aware } \\
\text { Property at } \\
\text { Risk Before } \\
\text { Flood }\end{array}$ & $\begin{array}{l}\text { Knows } \\
\text { What to Do } \\
\text { If Flooded }\end{array}$ & $\begin{array}{c}\text { Has } \\
\text { Contents } \\
\text { Insurance }\end{array}$ & $\begin{array}{c}\text { Took } \\
\text { Action }\end{array}$ & $\begin{array}{l}\text { Received } \\
\text { Warning }\end{array}$ & $\begin{array}{c}\text { Received } \\
\text { Assistance }\end{array}$ \\
\hline $\begin{array}{c}\text { All households } \\
\text { Child under } 10 \\
\text { years? }\end{array}$ & $1223(609)$ & 52 & 33 & 59 & 88 & 75 & 42 & 91 \\
\hline Yes & $160(55)$ & 40 & 43 & 58 & 88 & 84 & 46 & 95 \\
\hline No & $1063(554)$ & 54 & 32 & 59 & 88 & 74 & 41 & 90 \\
\hline Child $10-15$ years? & & & & & & & & \\
\hline Yes & $129(65)$ & 43 & 38 & 64 & 90 & 82 & 47 & 92 \\
\hline No & $1094(544)$ & 53 & 32 & 59 & 88 & 74 & 41 & 90 \\
\hline Adult $16-24$ years? & & & & & & & & \\
\hline Yes & $168(77)$ & 47 & 34 & 66 & 91 & 77 & 45 & 92 \\
\hline No & 1055 (532) & 53 & 33 & 58 & 88 & 75 & 41 & 90 \\
\hline Adult 25-69 years? & & & & & & & & \\
\hline Yes & 891 (439) & 50 & 35 & 62 & 89 & 77 & 42 & 90 \\
\hline No & $332(170)$ & 58 & 29 & 50 & 85 & 71 & 40 & 92 \\
\hline
\end{tabular}


Table 2. Cont.

\begin{tabular}{|c|c|c|c|c|c|c|c|c|}
\hline & \multirow[b]{2}{*}{$\begin{array}{c}\text { All } \\
\text { (Flooded) }\end{array}$} & \multicolumn{4}{|c|}{ Flood Preparedness } & \multicolumn{3}{|c|}{ Flood Mitigation } \\
\hline & & $\begin{array}{l}\text { Property- } \\
\text { Level Flood } \\
\text { Alleviation } \\
\text { Undertaken }\end{array}$ & $\begin{array}{l}\text { Was Aware } \\
\text { Property at } \\
\text { Risk Before } \\
\text { Flood }\end{array}$ & $\begin{array}{l}\text { Knows } \\
\text { What to Do } \\
\text { If Flooded }\end{array}$ & $\begin{array}{c}\text { Has } \\
\text { Contents } \\
\text { Insurance }\end{array}$ & $\begin{array}{c}\text { Took } \\
\text { Action }\end{array}$ & $\begin{array}{l}\text { Received } \\
\text { Warning }\end{array}$ & $\begin{array}{c}\text { Received } \\
\text { Assistance }\end{array}$ \\
\hline \multicolumn{9}{|l|}{$\begin{array}{c}\text { Adult over } 70 \\
\text { years? }\end{array}$} \\
\hline Yes & $271(148)$ & 57 & 27 & 51 & 88 & 71 & 37 & 93 \\
\hline No & $952(461)$ & 51 & 35 & 61 & 88 & 76 & 43 & 90 \\
\hline \multicolumn{9}{|l|}{ Disabled person? } \\
\hline Yes & $167(95)$ & 57 & 33 & 53 & 84 & 73 & 39 & 84 \\
\hline No & $958(457)$ & 50 & 33 & 61 & 90 & 76 & 42 & 92 \\
\hline \multicolumn{9}{|l|}{ Household income } \\
\hline$<£ 20,000$ per year & $371(172)$ & 51 & 32 & 54 & 83 & 66 & 43 & 87 \\
\hline$£ 20-50,000$ per year & 245 (117) & 46 & 45 & 63 & 96 & 89 & 45 & 93 \\
\hline $\begin{array}{c}£ 50,000+\text { per year } \\
\text { Highest } \\
\text { qualification }\end{array}$ & 54 (19) & 56 & 32 & 72 & 100 & 79 & 32 & 95 \\
\hline No quals & $184(111)$ & 51 & 28 & 63 & 90 & 72 & 46 & 89 \\
\hline Lower sec. school & $108(47)$ & 44 & 32 & 63 & 88 & 70 & 32 & 92 \\
\hline Higher sec. school & $78(36)$ & 62 & 26 & 65 & 91 & 75 & 31 & 89 \\
\hline Lower vocational & $58(28)$ & 52 & 50 & 60 & 87 & 79 & 46 & 82 \\
\hline Higher vocational & $59(34)$ & 54 & 33 & 60 & 85 & 71 & 32 & 97 \\
\hline $\begin{array}{c}\text { Higher National Cert } \\
\text { or Diploma }\end{array}$ & $92(37)$ & 36 & 31 & 62 & 97 & 76 & 47 & 92 \\
\hline Degree or higher & $174(66)$ & 47 & 39 & 59 & 89 & 82 & 55 & 94 \\
\hline Professional quals & $160(74)$ & 51 & 33 & 60 & 95 & 76 & 32 & 93 \\
\hline
\end{tabular}

Source: Authors' survey. Bold indicates statistically significant differences between categories (moving down a column labelled in italics) within a group (in non-italics above the category labels) at the $95 \%$ level according to the Chi-square test.

Table 3. Flood resilience by housing and residential characteristics. (\% of households).

\begin{tabular}{|c|c|c|c|c|c|c|c|c|}
\hline & \multirow[b]{2}{*}{$\begin{array}{c}\text { All } \\
\text { (Flooded) }\end{array}$} & \multicolumn{4}{|c|}{ Flood Preparedness } & \multicolumn{3}{|c|}{ Flood Mitigation } \\
\hline & & $\begin{array}{l}\text { Property- } \\
\text { Level Flood } \\
\text { Alleviation } \\
\text { Undertaken }\end{array}$ & $\begin{array}{c}\text { Was Aware } \\
\text { Property at } \\
\text { Risk Before } \\
\text { Flood }\end{array}$ & $\begin{array}{l}\text { Knows } \\
\text { What to Do } \\
\text { If Flooded }\end{array}$ & $\begin{array}{c}\text { Has } \\
\text { Contents } \\
\text { Insurance }\end{array}$ & $\begin{array}{c}\text { Took } \\
\text { Action }\end{array}$ & $\begin{array}{l}\text { Received } \\
\text { Warning }\end{array}$ & $\begin{array}{c}\text { Received } \\
\text { Assistance }\end{array}$ \\
\hline $\begin{array}{l}\text { All households } \\
\text { Housing tenure }\end{array}$ & $1223(609)$ & 52 & 33 & 59 & 88 & 75 & 42 & 91 \\
\hline $\begin{array}{c}\text { Being bought with a } \\
\text { mortgage }\end{array}$ & 467 (216) & 45 & 34 & 65 & 96 & 78 & 40 & 88 \\
\hline $\begin{array}{c}\text { Owned outright by } \\
\text { household }\end{array}$ & $400(234)$ & 59 & 32 & 62 & 95 & 76 & 37 & 91 \\
\hline Rented from council & $181(84)$ & 60 & 35 & 44 & 69 & 69 & 49 & 95 \\
\hline $\begin{array}{c}\text { Rented from a } \\
\text { housing ass./trust }\end{array}$ & $36(12)$ & 36 & 36 & 46 & 43 & 58 & 33 & 100 \\
\hline $\begin{array}{l}\text { Rented from a } \\
\text { private landlord } \\
\text { Housing type }\end{array}$ & $55(14)$ & 26 & 8 & 55 & 67 & 64 & 54 & 100 \\
\hline Detached & $206(99)$ & 59 & 38 & 61 & 93 & 68 & 24 & 86 \\
\hline Semi-detached & 177 (102) & 59 & 25 & 64 & 93 & 78 & 33 & 94 \\
\hline Terraced & $427(248)$ & 49 & 35 & 63 & 90 & 79 & 52 & 92 \\
\hline $\begin{array}{c}\text { Flat } \\
\text { Duration of } \\
\text { residence }\end{array}$ & $257(72)$ & 44 & 36 & 51 & 85 & 71 & 28 & 90 \\
\hline $0-3$ years & 247 (27) & 38 & 39 & 39 & 79 & 78 & 38 & 93 \\
\hline $4-9$ years & 277 (114) & 49 & 50 & 60 & 85 & 71 & 49 & 90 \\
\hline $10+$ years & 637 (429) & 58 & 29 & 67 & 90 & 77 & 40 & 90 \\
\hline
\end{tabular}

Source: Authors' survey. Bold indicates statistically significant differences between categories (moving down a column labelled in italics) within a group (in non-italics above the category labels) at the $95 \%$ level according to the Chi-square test.

Specifically, homeowners without a mortgage, council tenants and those living in detached or semi-detached houses display markedly higher rates of property-level flood alleviation (Table 3). Households who have lived in their property for longer are more likely to have adopted property-level flood alleviation (Table 3). Most of these associations 
are also evident in multivariate relationships found among those who have moved into a property since the flood, although after controlling for confounding between factors, demographic characteristics become important (households with an elderly member or children being less likely to have undertaken property-level flood alleviation) and duration of residence ceases to be statistically significant. These groups may have lower income and/or less time available with which to undertake property adaptations. Having been previously flooded or living in the area when the flood event occurred have strong positive influences on the adoption of property-level flood alleviation (Table 4).

Table 4. Flood resilience by flood history. (\% of households).

\begin{tabular}{|c|c|c|c|c|c|c|c|c|}
\hline & \multirow[b]{2}{*}{$\begin{array}{c}\text { All } \\
\text { (Flooded) }\end{array}$} & \multicolumn{4}{|c|}{ Flood Preparedness } & \multicolumn{3}{|c|}{ Flood Mitigation } \\
\hline & & $\begin{array}{l}\text { Property- } \\
\text { Level Flood } \\
\text { Alleviation } \\
\text { Undertaken }\end{array}$ & $\begin{array}{l}\text { Was Aware } \\
\text { Property at } \\
\text { Risk Before } \\
\text { Flood }\end{array}$ & $\begin{array}{l}\text { Knows } \\
\text { What to Do } \\
\text { If Flooded }\end{array}$ & $\begin{array}{c}\text { Has } \\
\text { Contents } \\
\text { Insurance }\end{array}$ & $\begin{array}{c}\text { Took } \\
\text { Action }\end{array}$ & $\begin{array}{l}\text { Received } \\
\text { Warning }\end{array}$ & $\begin{array}{l}\text { Received } \\
\text { Assistance }\end{array}$ \\
\hline $\begin{array}{l}\text { All households } \\
\text { Flooded? }\end{array}$ & $1223(609)$ & 52 & 33 & 59 & 88 & 75 & 42 & 91 \\
\hline Yes & 609 (609) & 66 & 33 & 66 & 89 & 75 & 42 & 91 \\
\hline No & $614(0)$ & 38 & $\mathrm{n} / \mathrm{a}$ & 53 & 71 & $\mathrm{n} / \mathrm{a}$ & $\mathrm{n} / \mathrm{a}$ & $\mathrm{n} / \mathrm{a}$ \\
\hline $\begin{array}{c}\text { Lived in property } \\
\text { at time of flood } \\
\text { event? }\end{array}$ & & & & & & & & \\
\hline Yes & 760 (609) & 58 & 32 & 66 & 88 & 75 & 42 & 90 \\
\hline No & $342(0)$ & 36 & $\mathrm{n} / \mathrm{a}$ & 44 & 77 & $\mathrm{n} / \mathrm{a}$ & $\mathrm{n} / \mathrm{a}$ & $\mathrm{n} / \mathrm{a}$ \\
\hline
\end{tabular}

Source: Authors' survey. Bold indicates statistically significant differences between categories (moving down a column labelled in italics) within a group (in non-italics above the category labels) at the $95 \%$ level according to the Chi-square test.

Multivariate models control for confounding factors (Table 5) and differentiate between those who lived in their property at the time of the flood event and those who have moved in since the flood event (Table 6). This distinction is important for two reasons: firstly, those who lived in their property at the time of the flood event are almost inevitably aware that they are at flood risk, thus providing a natural experiment in terms of the effect of knowledge on behaviour; and, secondly, contrasting findings between these two groups can inform different community engagement strategies and flood risk management targeting in different areas depending on whether they have previously been flooded or not. In-movers were modelled on only two elements of flood resilience: property-level flood alleviation and knowledge of what to do if flooded. Contents insurance is not reported as it did not reveal any differences between the two groups, and a question of knowledge of flood risk when moved in was asked but had too few responses to allow reliable statistical analysis.

Questions on mitigation only applied to those who had been flooded. Two key differences between these groups can be seen. First, more demographic and housing factors are statistically significantly related to uptake of property-level flood alleviation among the in-movers (elderly, those with children and those in terraced houses or flats less likely (across all survey sites, a maximum of $10 \%$ of upper floor properties was included in the total sample on the basis that residents on upper floor flats only have communal areas, utilities and vehicles at direct risk from flood water but not their home itself)) compared to those resident at the time of the flood-this finding suggests that a flood event encourages the uptake of flood alleviation measures among laggard groups, thus reducing social differentiation. Terraced housing and flats having lower levels of flood alleviation measures among in-movers since the flood events may be explained by the greater complexity in organising property adaptations with shared walls and communal features, but the necessity of taking action after a flood goes some way to circumventing these challenges. Second, council tenants are more likely to live in properties with flood alleviation measures after the flood events, but before the flood, council properties were less likely to have flood alleviation measures-this finding suggests that councils (local 
government) act to implement property-level flood alleviation measures after a flood but not before a flood.

Table 5. Multivariate models of factors associated with flood resilience-households who lived in the property at time of flood event. (Odds ratios).

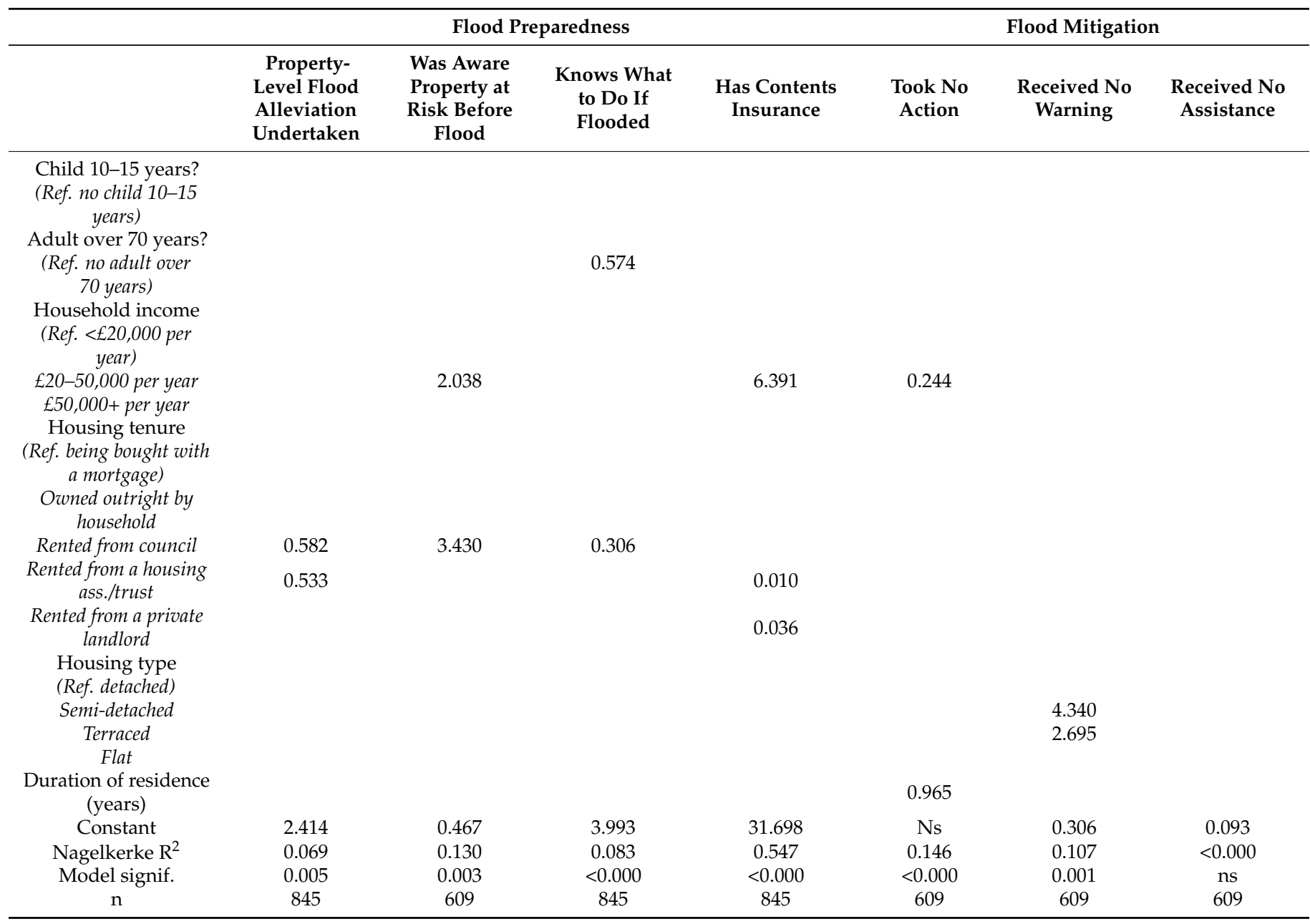

Table 6. Multivariate models of factors associated with property-level flood alleviation and knowledge of what to do if flooded-hose living in property at time of flood event versus those moved into property since flood event. (Odds ratios).

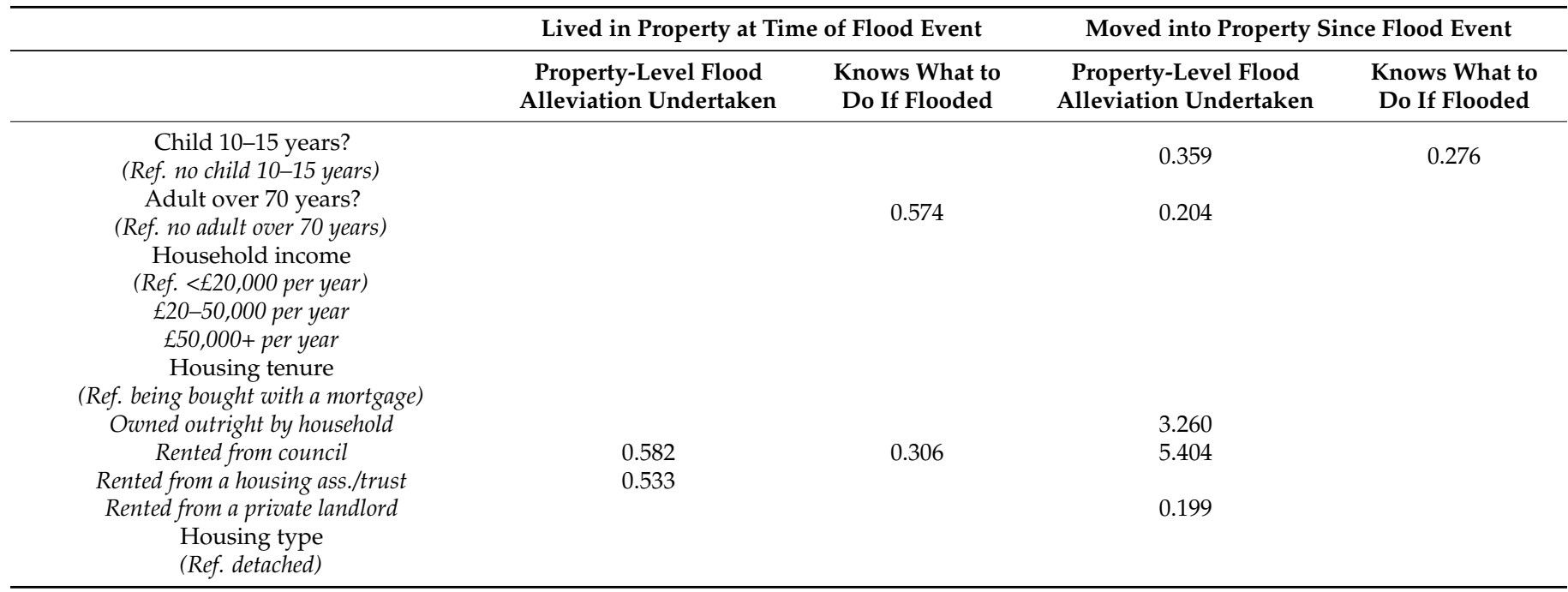


Table 6. Cont

\begin{tabular}{|c|c|c|c|c|}
\hline & \multicolumn{2}{|c|}{ Lived in Property at Time of Flood Event } & \multicolumn{2}{|c|}{ Moved into Property Since Flood Event } \\
\hline & $\begin{array}{l}\text { Property-Level Flood } \\
\text { Alleviation Undertaken }\end{array}$ & $\begin{array}{l}\text { Knows What to } \\
\text { Do If Flooded }\end{array}$ & $\begin{array}{l}\text { Property-Level Flood } \\
\text { Alleviation Undertaken }\end{array}$ & $\begin{array}{l}\text { Knows What to } \\
\text { Do If Flooded }\end{array}$ \\
\hline \multicolumn{5}{|l|}{ Semi-detached } \\
\hline Terraced & & & 0.338 & \\
\hline Flat & & & 0.282 & 0.420 \\
\hline Duration of residence (years) & & & & 1.245 \\
\hline Constant & 2.414 & 3.993 & Ns & ns \\
\hline Nagelkerke $\mathrm{R}^{2}$ & 0.069 & 0.083 & 0.223 & 0.121 \\
\hline Model signif. & 0.005 & $<0.000$ & $<0.000$ & 0.001 \\
\hline $\mathrm{n}$ & 845 & 845 & 311 & 311 \\
\hline
\end{tabular}

The prevalence of contents insurance is positively associated with higher income (Table 2), homeownership (Table 3) and having been previously flooded (Table 4). Multivariate analysis confirms the importance of household income and housing tenure in the uptake of contents insurance after controlling for confounding factors (Table 5).

In terms of flood knowledge, it is younger households, particularly those with children, who report greater levels of awareness that their property was at flood risk prior to being flooded (Table 2). In contrast, however, older households (those with someone aged over 70 years) had better knowledge of what to do if flooded, despite being less aware that they were at risk of flooding (Table 2). Higher income households are more likely to know what to do if flooded, yet it is middle-income households that reported the greatest awareness of being at flood risk prior to the flood event (Table 2). As with income, duration of residence also displays an inverted ' $U$ '-shaped relationship with flood awareness, with both recent arrivals and long-term residents reporting low awareness of flood risk. However, duration of residence displays a more consistent relationship with knowledge of what to do if flooded, with length of residence associated with greater knowledge (Table 3). Homeowners report greater knowledge of what to do if flooded than renters (Table 3), but there are no housing tenure differences in levels of knowledge of flood risk. Having been flooded substantially raises knowledge of what to do if flooded (Table 4).

Many of these statistically significant associations disappear (although one new one appears and one changes sign-see below) in multivariate models that control for confounding between factors (Table 5). Specifically, after controls, older households are less, rather than more, likely to know what to do if flooded; and council tenants are more, rather than less, likely to be aware that they are at flood risk. Overall, however, the most important message from multivariate models of flood preparedness is how few demographic, social or housing factors are statistically significantly associated with any of the measures of flood preparedness. Particularly important from a knowledge-deficit model of behaviour change, education as measured by highest qualification is not statistically significantly linked to any of the measures of flood preparedness.

\subsection{Mitigation}

During the flood event, families with young children, middle- and higher-income households (Table 2) and homeowners (Table 3) were the most likely to take action in order to mitigate the impact of the flood. However, after controls for confounding, only income and duration of residence increase the likelihood of taking action to mitigate the impact of the flood (Table 5).

There are no demographic or social (Table 2) or housing tenure (Table 3) differences in the likelihood of receiving a flood warning or receiving assistance, with the exception of households with a disabled person, who are less likely to report having received assistance (Table 2), although this effect is not present after controls (Table 5). Those living in a detached house are the least likely to receive either a warning or assistance (Table 3), although this effect for receiving a warning reverses after controls (Table 5). Those living in a terraced house were substantially more likely to receive a flood warning (Table 3), 
although this effect reverses after controls (Table 5). Those in flats and terraced housing being more likely to have received a flood warning (before controls) may be accounted for due to greater proximity to neighbours in these types of housing. In multivariate models, no demographic, social, housing or residential factor is statistically significantly associated with having received assistance (Table 5). Education as measured by highest qualification is not statistically significantly linked to any of the mitigation measures (or to any of the preparedness measures, as reported in the previous section).

\section{Discussion}

The analysis of social patterns in flood preparedness and mitigation reported in this paper is based on one of the largest and most representative surveys of flooded households and those living in flood-risk areas to date. The sample's representativeness and inclusion of small-scale flood events may account for the lack of substantial social patterns revealed in flood preparedness and mitigation, in contrast to existing studies that tend to have focused on large, high-profile floods, in which social disparities may be greater.

Nevertheless, there are some important, if unsurprising, findings, that confirm some assumptions in the existing literature on flood risk management. First, having been previously flooded and duration of residence raise preparedness (consistent with Geddes et al. [32]). Second, older people and those on lower incomes have lower preparedness and are less likely to take or receive mitigating actions or assistance (consistent with arguments in Tunstall et al. [30], Medd et al. [10], Watkiss et al. [25], Penning-Rowsell [24] and Sayers et al. [4]). Third, those with children, those with a mortgage and those in terraced housing or flats are less likely to undertake property-level flood alleviation work (consistent with arguments in Tunstall et al. [30], Sayers et al. [4] and Glencross et al. [22]). These groups may have lower disposable income, and/or less time and less practical scope (in terms of terraced housing and flats) to undertake property adaptations (as discussed in Medd et al. [10]). These findings may help inform, and provide evidence to support, the targeting of assistance schemes to increase flood preparedness.

However, some other findings are more surprising and, in contrast with prevailing assumptions in existing literature, point to a remarkable lack of importance of social factors in shaping flood preparedness and mitigation. In particular, none of the social factors examined are linked with the probability of having received help during a flood, with assistance being available relatively ubiquitously ( $91 \%$ of flooded households received assistance from a variety of formal services and informal sources). Education as measured by highest qualification is not statistically significantly linked to any of the measures of flood preparedness or mitigation in multivariate models, and in the descriptive analyses (Tables 2 and 3) those with higher levels of education are actually slightly less likely to have implemented property-level flood alleviation measures. The complete lack of importance of level of education in accounting for any aspect of flood preparedness or mitigation surely puts a final nail in the coffin of the knowledge-deficit model of flood vulnerability and resilience, with multiple and complex factors shaping behavioral responses (as outlined in Glencross et al. [22].

Our household survey is based on random sampling of all households who live within the flood envelopes of flood events that took place in the previous 1-12 years, almost exactly half of which were flooded. As such, levels of flood preparedness could be expected to be somewhat lower in flood-risk areas that have not experienced a flood event in recent living memory. Nevertheless, the analysis reported in this paper is concerned with social patterns in, not absolute levels of, flood preparedness, thus somewhat nullifying the issue, unless flood events serve to raise preparedness in socially-differentiated ways. The parts of the analysis that deal with flood mitigations (e.g., receiving assistance), by definition, only apply to households that have experienced a flood, so the flood mitigation analysis is unaffected by the sample being drawn from areas that have experienced recent floods.

A limitation of our data is that they were collected retrospectively and therefore are subject to recall bias and error. Nevertheless, focus groups conducted with some of 
the survey respondents revealed vivid and detailed memories of flood events and their aftermath, at least among those who volunteered to take part in focus groups (reported in Werritty et al. [8]).

People who left flooded areas or died between the flood and the survey are not captured in the group of flooded households within the sample. The sample as a whole somewhat over-represents older people and homeowners but its socio-economic composition is broadly representative of the Scottish population as a whole (see figures reported in the 'Sampling and data collection' section). The sample is a random selection of all residential addresses in areas after a range of large and small fluvial, coastal or urban surface water pluvial floods, making it more representative than some previous surveys (e.g., the study of Tunstall et al. [30] was limited to fluvial floods and Lamond et al. [31] to homeowners). Although the sample is larger than most other studies, some categories have small numbers of observations (e.g., private renters).

A further limitation with our data is that it only captures the presence or absence of the seven preparedness and mitigation features, and the majority of households register many of them. Our data do not capture the quantity, quality or effectiveness of these preparedness and mitigation features, which may display social differences. Nevertheless, the limited evidence of social differentiation revealed by our analysis indicates that social factors at best only explain a small proportion of the variation between households in flood preparedness and mitigation measures. Despite this, however, more substantial social differences reveal themselves in the long-term impacts on social and mental wellbeing [7] but the results of our analysis reported here suggest that the causes of this appear to be deep-seated social stratification and inequality rather than large social differences in flood preparedness and mitigation measures.

\section{Conclusions}

This paper has revealed, based on a large and representative survey of households in flooded areas, that flood preparedness and mitigation are only weakly linked with social factors. Around half our sample had been previously flooded and a further quarter lived in the area at the time of the flood event, but their home escaped damage. This sample design allowed us to investigate flood mitigations after a flood (e.g., receiving a flood warning or assistance) but may reflect different social patterns of flood preparedness (e.g., undertaking property-level alleviation measures) compared to a flood-risk area that has not experienced a recent flood. For instance, it may be that a flood event increases preparedness the most amongst groups with the lowest levels of pre-flood preparedness, such as lower socio-economic groups. Therefore, further research could be undertaken on social patterns in flood preparedness in flood-risk areas that have not experienced recent floods.

Our findings reveal that lower educated groups and those in suburban houses (as opposed to terraced houses or flats) are no less likely, and in some cases are more likely, to be better prepared for, or able to deal with, a flood. Older age groups, lower-income households and renters do, however, record lower levels of flood preparedness and/or mitigation.

None of the social factors examined are linked with the probability of having received help during a flood. This points to household, social and community resilience in the immediate aftermath of a flood being generally well developed and able to reach most sections of the community.

Education as measured by highest qualification is not statistically significantly linked to any of the measures of flood preparedness or mitigation. The lack of importance of education in particular is a challenge to the techno-rational assumptions and the knowledgedeficit model underpinning some existing flood vulnerability and resilience research literature and flood risk management policy and practice, which often seek to 'correct' the knowledge deficit as a key factor thought to limit the uptake of flood preparedness and mitigation measures. 
We found that having been previously flooded and the duration of residence in an area both raise preparedness. This finding supports existing practice in flood risk management to encourage action from residents immediately after a flood and to raise awareness among new arrivals in an area who have not witnessed a flood.

Existing literature points to social inequalities in exposure to flood risk, particularly coastal flooding and surface water flooding in urban areas [2,29,42]. In addition, the impacts of being flooded also appear to be more acutely felt by socially disadvantaged groups, particularly in the long term [7]. Houston et al. [7] found small and counter-intuitive social patterns (e.g., professionals and homeowners) in reported impacts on households in the immediate aftermath of a flood, but social inequalities appeared in long-term impacts. This finding of social inequalities widening over the recovery process is consistent with our finding of relatively few and small social differences in flood preparedness and mitigation. Thus, the recovery from floods is driven by social inequalities, but the roots of these unequal outcomes lie largely in deep-seated social structures and inequalities rather than in social differences in flood preparedness and mitigation. A policy consequence is that social targeting of flood awareness and preparedness campaigns is not likely to be widely necessary-it is better simply to raise awareness and encourage preparedness across the social spectrum. General poverty and inequality alleviation measures, such as tax and welfare policy and urban and community regeneration schemes, that can help build household and community 'resourcefulness' in a wider sense than narrow resilience to a specific hazard [43], are likely to be as, if not more, important in alleviating social inequalities in the long-term impacts of floods than social targeting of a flood risk management policy.

Author Contributions: Conceptualization, D.H.; methodology, D.H., A.R.B. and A.W.; formal analysis, D.H.; data collection, D.H. and T.B.; writing-original draft preparation, D.H. and T.B.; writingreview and editing, D.H., T.B., A.R.B. and A.W.; supervision, D.H. and A.R.B.; project administration, A.W.; funding acquisition, D.H., A.R.B. and A.W. All authors have read and agreed to the published version of the manuscript.

Funding: This research received no external funding.

Institutional Review Board Statement: The original data collection was conducted under the guidelines of the research ethics committee of the University of Dundee.

Informed Consent Statement: Informed consent was obtained from all subjects involved in the study.

Data Availability Statement: The data were collected subject to stringent confidentiality and security guarantees given to participants, which could potentially be breached due to the detailed information on individual household circumstances and locations in the dataset, therefore the dataset cannot be made publicly available.

Acknowledgments: We are indebted to the Scottish Government for funding the original study, all survey respondents and Amy Tavendale for undertaking the bulk of the data collection and subsequent data entry and checking.

Conflicts of Interest: The authors declare no conflict of interest.

\section{References}

1. Fielding, J.; Burningham, K. Environmental inequality and flood hazard. Local Environ. 2005, 10, 379-395. [CrossRef]

2. Houston, D.; Werritty, A.; Basset, D.; Geddes, A.; Hoolachan, A.; Mcmillan, M. Pluvial Flood Risk in Urban Areas: The Invisible Hazard; The Policy Press with the Joseph Rowntree Foundation: Bristol, UK, 2011.

3. Kaźmierczak, A.; Cavan, G.; Connelly, A.; Lindley, S. Mapping Flood Disadvantage in Scotland 2015: Main Report; Scottish Government: Edinburgh, UK, 2015. Available online: https://www.gov.scot/publications/mapping-flood-disadvantagescotland-2015-main-report/ (accessed on 27 January 2020).

4. Sayers, P.; Penning-Rowsell, E.C.; Horritt, M. Flood vulnerability, risk and social disadvantage: Current and future patterns in the UK. Reg. Environ. Chang. 2018, 18, 339-352. [CrossRef]

5. Lindley, S.; O’Neill, J.; Kandeh, J.; Lawson, N.; Christian, R.; O'Neill, M. Climate Change, Justice and Vulnerability; Joseph Rowntree Foundation: York, UK, 2011. 
6. Sayers, P.B.; Horritt, M.S.; Penning-Rowsell, E.C.; Mckenzie, A. Appendix A Supporting data sets, Appendix E Individual adaptation measures, and Appendix F The Future Flood Explorer Overview. In Climate Change Risk Assessment 2017: Projections of Future Flood Risk in the UK; A Sayers and Partners LLP report for the Committee on Climate Change; Committee on Climate Chang: London, UK, 2015. Available online: https:/ / www.theccc.org.uk/publication/sayers-for-the-asc-projections-of-futureflood-risk-in-the-uk/ (accessed on 27 January 2020).

7. Houston, D.; Werritty, A.; Ball, T.; Black, A. Environmental vulnerability and resilience: Social differentiation in short- and long-term flood impacts. Trans. Inst. Br. Geogr. 2020, 46, 102-119. [CrossRef]

8. Werritty, A.; Houston, D.; Ball, T.; Tavendale, A.; Black, A. Exploring the Social Impacts of Flood Risk and Flooding in Scotland; Scottish Executive Central Research Unit: Edinburgh, UK, 2007; 157p. Available online: https://www.webarchive.org.uk/wayback/ archive/20150219020106/http:/ /www.gov.scot/Publications/2007/04/02121350/0 (accessed on 2 April 2007).

9. Sims, R.; Medd, W.; Mort, M.; Twigger-Ross, C. When a "home" becomes a "house": Care and caring in the flood recovery process. Space Cult. 2009, 12, 303-316. [CrossRef]

10. Medd, W.A.; Deeming, H.B.; Walker, G.A.; Whittle, R.A.; Mort, M.D.; Twigger-Ross, C.E.; Walker, M.A.; Watson, N.A.; Kashefi, E.C. The flood recovery gap: A real-time study of local recovery following the floods of June 2007 in Hull, North East England. J. Flood Risk Manag. 2015, 8, 315-328. [CrossRef]

11. Tapsell, S.; Penning-Rowsell, E.C.; Tunstall, S.M.; Wilson, T.L. Vulnerability to Flooding: Health and Social Dimensions. Philos. Trans. R. Soc. A 2002, 360, 1511-1525. [CrossRef]

12. Watson, N.; Kashefi, E.; Medd, W.; Tapsell, S.; Twigger-Ross, C.; Walker, G. Institutional and social responses to flooding from a resilience perspective. In Flood Risk Management: Research and Practice; Samuels, P., Huntington, S., Allsop, W., Harrop, J., Eds.; Taylor \& Francis Group: London, UK, 2009; pp. 911-917.

13. Watts, M.; Bohle, H. The space of vulnerability: The causal structure of hunger and famine. Prog. Hum. Geogr. 1993, $17,43-67$. [CrossRef]

14. Cutter, S.L.; Boruff, B.J.; Shirley, W.L. Social vulnerability to environmental hazards. Soc. Sci. Q. 2003, 84, 242-261. [CrossRef]

15. Johnson, C.; Penning-Rowsell, E.; Parker, D. Natural and imposed injustices: The challenges in implementing 'fair' flood risk management policy in England. Geogr. J. 2007, 173, 374-390. [CrossRef]

16. McCarthy, J. Authoritarianism, Populism, and the Environment: Comparative Experiences, Insights, and Perspectives. Ann. Am. Assoc. Geogr. 2019, 109, 301-313. [CrossRef]

17. Kaźmierczak, A.; Cavan, G.; Connelly, A.; Lindley, S. Mapping Flood Disadvantage in Scotland 2015: Methodology Report; Scottish Government: Edinburgh, UK, 2015. Available online: https://www.gov.scot/publications/mapping-flood-disadvantagescotland-2015-methodology-report/pages / 4/ (accessed on 27 January 2020).

18. Cutter, S. Vulnerability to Environmental Hazards. In Hazards, Vulnerability and Environmental Justice; Cutter, S., Ed.; Earthscan: London, UK, 2006; pp. 71-82.

19. Davidson, J.L.; Jacobson, C.; Lyth, A.; Dedekorkut-Howes, A.; Baldwin, C.L.; Ellison, J.C.; Holbrook, N.J.; Howes, M.J.; SerraoNeumann, S.; Singh-Peterson, L.; et al. Interrogating resilience: Toward a typology to improve its operationalization. Ecol. Soc. 2016, 21, 27. [CrossRef]

20. Thurston, N.; Finlinson, B.; Breakspear, R.; Williams, N.; Shaw, J.; Chatterton, J. Developing the Evidence Base for Flood Resistance and Resilience: RED Summary Report FD2607/TR1; Department of Environment, Food and Rural Affairs, UK Government: London, UK, 2008. Available online: https://assets.publishing.service.gov.uk/media/602e84bde90e076606603777/Developing_the_evidence_ base_for_flood_resistance_and_resilience_report.pdf (accessed on 8 August 2021).

21. Scottish Government. Living with Flooding: An Action Plan for Delivering Property Flood Resilience in Scotland; Property Flood Resilience Group, Scottish Government: Scotland, UK, 2019. Available online: https://www.gov.scot/publications/livingflooding-action-plan-delivering-property-flood-resilience-scotland/ (accessed on 27 January 2020).

22. Glencross, K.; Warren, R.; Eunson, J.; Ansons, T. Understanding the Barriers to Uptake of Property Flood Resilience (PFR) in Scotland, Ipsos Mori on Behalf of Climate X Change; Ipsos MORI: London, UK, 2021. [CrossRef]

23. Ball, T.; Werritty, A.; Geddes, A. Insurance and sustainability in flood-risk management: The UK in a transitional state. Area 2013, 45, 266-272. [CrossRef]

24. Penning-Rowsell, E.C. Flood insurance in Scotland: A cause for serious concern. Scott. Geogr. J. 2019, 135, 33-45. [CrossRef]

25. Watkiss, P.; Cimato, F.; Hunt, A.; Morley, B. Climate Change Impacts on the Future Cost of Living (SSC/CCC004); Joseph Rowntree Foundation: York, UK, 2016. Available online: http://www.paulwatkiss.co.uk/documents/FINAL\%20Watkiss\%20report\%2030 032016.pdf (accessed on 8 August 2021).

26. Browning, S. Household Flood Insurance: Flood Re, House of Commons Briefing Paper, 8751, Commons. 2021. Available online: https:/ / commonslibrary.parliament.uk/research-briefings/cbp-8751/ (accessed on 8 August 2021).

27. Pitt, M. Learning Lessons from the 2007 Floods: An Independent Review by Sir Michael Pitt; Interim Report (The Pitt Review); U.K. Government: London, UK, 2007; pp. 32-33.

28. Rözer, V.; Surminski, S. Current and future flood risk of new build homes across different socio-economic neighbourhoods in England and Wales. Environ. Res. Lett. 2021, 16, 054021. [CrossRef]

29. Walker, G.; Burningham, K. Flood risk, vulnerability and environmental justice: Evidence and evaluation of inequality in a UK context Crit. Soc. Policy 2011, 31, 216-240. [CrossRef] 
30. Tunstall, S.; Tapsell, S.; Green, C.; Floyd, P.; George, C. The health effects of flooding: Social research results from England and Wales. J. Water Health 2006, 4, 365-380. [CrossRef] [PubMed]

31. Lamond, J.E.; Joseph, R.D.; Proverbs, D.G. An exploration of factors affecting the long term psychological impact and deterioration of mental health in flooded households. Environ. Res. 2015, 140, 325-334. [CrossRef] [PubMed]

32. Geddes, A.; Cranston, M.; Ambler, A.; Black, A.R. 2017 Assessing the Effectiveness of Scotland's Public Flood Warning Service: Full Report CRW2016_12. Available online: crew.ac.uk/publications (accessed on 14 September 2017).

33. Thrush, D.; Burningham, K.; Fielding, L. Flood Warning for Vulnerable Groups: A Review of Literature-Report S. W5C-0181/1; Environment Agency Science: Bristol, UK, 2005. Available online: https://assets.publishing.service.gov.uk/government/ uploads/system/uploads/attachment_data/file/290693/scho0505bjbr-e-e.pdf (accessed on 8 August 2021).

34. Penning-Rowsell, E.; Wilson, T. Gauging the impact of natural hazards: The pattern and cost of emergency response during flood events. Trans. Inst. Br. Geogr. 2006, 31, 99-115. [CrossRef]

35. Cutter, S.L.; Barnes, L.; Berry, M.; Burton, C.; Evans, E.; Tate, E.; Webb, J. A place-based model for understanding community resilience to natural disasters. Glob. Environ. Chang. 2008, 18, 598-606. [CrossRef]

36. Tapsell, S.M.; Tunstall, S.M. "I wish I'd never been to Banbury": The relationship between 'place' and the health impacts from flooding. Health Place 2008, 14, 133-154. [CrossRef]

37. Greene, G.; Paranjothy, S.; Palmer, S.R. Resilience and vulnerability to the psychological harm from flooding: The role of social cohesion. Am. J. Public Health 2015, 105, 1792-1795. [CrossRef] [PubMed]

38. Masozera, M.; Bailey, M.; Kerchner, C. Distribution of impacts of natural disasters across income groups: A case study of New Orleans. Ecol. Econ. 2007, 63, 299-306. [CrossRef]

39. Cutter, S.L.; Ash, K.D.; Emrich, C.T. The geographies of community disaster resilience. Glob. Environ. Chang. 2014, $29,65-77$. [CrossRef]

40. Finch, C.; Emrich, C.T.; Cutter, S.L. Disaster disparities and differential recovery in New Orleans. Popul. Environ. 2010, 31, 179-202. [CrossRef]

41. Black, A.R.; Burns, J.C. Re-assessing the flood risk in Scotland. Sci. Total Environ. 2002, 294, 169-184. [CrossRef]

42. Kaźmierczak, A.; Cavan, G. Surface water flooding risk to urban communities: Analysis of vulnerability, hazard and exposure. Landsc. Urban Plan. 2011, 103, 185-197. [CrossRef]

43. MacKinnon, D.; Derickson, K. From resilience to resourcefulness: A critique of resilience policy and activism. Prog. Hum. Geogr. 2013, 37, 253-270. [CrossRef] 